\title{
MJN WILINGNESS TO BE VACCINATED AGAINST COVID-19 AMONG HIGHER EDUCATION INSTITUTION
}

\author{
Joel Rey Acob ${ }^{1 *}$, Moises Neil V. Seriño ${ }^{2}$, Reyvin N. Sabanal ${ }^{2}$, Therese C. Ratilla ${ }^{3}$, Elwin Jay $\mathrm{Yu}^{4}$, \\ Lilian B. Nuñez ${ }^{5}$, Maria Hazel I. Bellezas ${ }^{6}$ \\ ${ }^{1}$ College of Nursing, Visayas State University, Baybay City, Leyte, Philippines \\ ${ }^{2}$ College of Management and Economics, Visayas State University, Baybay City, Leyte, Philippines \\ ${ }^{3}$ Visayas Socio-Economic Research and Data Analytics Center, Visayas State University, Baybay City, Leyte, \\ Philippines \\ ${ }^{4}$ University Services for Health, Emergency and Rescue, Baybay City, Leyte, Philippines \\ Institute for Strategic Research and Development Studies, Visayas State University, Baybay City, Leyte, \\ Philippines \\ ${ }^{\circ}$ Department of Economics, Visayas State University, Baybay City, Leyte, Philippines \\ *Corresponding Author's Email: joel.acob@vsu.edu.ph
}

\begin{abstract}
Introduction: The increasing COVID-19 cases worldwide ignite pharmaceutical companies' effort to discover safe vaccines have been eyed globally. Informed perspectives across medical profession explaining beneficial effects of inoculation, however, various personal views persist which lead to confusion among general public. Objectives: Describe demographic characteristics among education institutions and their willingness to be vaccinated. Methods: Via google forms, data are collected in February 2021. The online form was then pre-tested to 10 respondents to refine questions prior to commencing the survey. Convenience sampling was administered for the selection of voluntary respondents. Data cleaning was done prior to the data analysis. Recoding of string variables and omitting of invalid responses were also done. Descriptive statistics was undertaken in a genuine licensed software of IBM SPSS Statistics version 26. Results: A total of 401 respondents answered the survey. More than half of the respondents are female constituting $62.1 \%$ of the sample, whereas males constitute $37.9 \%$, mostly faculty members, single $(63.1 \%)$, earning $20,000(54.2 \%)$ pesos monthly. More than half of the respondents are willing to get vaccinated against COVID-19(54.6\%) and have no preference for a specific type of COVID-19 vaccine (54.9\%). Around $30.4 \%$ are still unsure if they should get vaccinated or not and $15 \%$ have indicated negatively. Comparing both sexes, a larger frequency of males are willing to get vaccinated constituting $69.1 \%$ than females $(45.8 \%)$. Conclusion: Males manifest more willingness to be inoculated regardless of COVID-19 vaccine types. Education and continuous campaign on the importance of vaccination program is a must to increase success rate to end the health crisis.
\end{abstract}

Keywords: Caring; Covid-19; Gender; Higher Education; Vaccination Hesitancy

\section{INTRODUCTION}

COVID-19 pandemic severely hit the entire world which poses a great threat in the national security, physical health, mental health, food security and economy. People are driven to take preventive and protective measures to regulate the spread of virus. The World Health Organization (WHO) and health ministries urged a strict implementation of wearing face masks, observing social-distancing, area-wide lockdowns and curfews to ensure safety of each individual. Globally, as of January 24, 2021, there have been 97,464,094 confirmed cases of COVID-19, including 2,112,689 deaths, reported to WHO. Efforts are being made globally to take action in the development of an effective, safe and acceptable vaccine that is an essential tool to fight against the virus (Mundra \& Garg, 2020).

Mundra \& Garg (2020) reported that vaccine development critically is a long process, and sometime, it takes several years to develop. However, in COVID-19 case, since there is a global crisis, everybody is hoping for an early vaccine. The positive development and availability of COVID-19 vaccines approved for being administered to general public is 
considered a breakthrough in science which a step closer in ending this global crisis. With the success of COVID-19 vaccines, the attention has turned towards vaccine distribution and its uptake. Countries around the globe are now implementing their respective COVID-19 vaccination programs (The ASEAN Post, 2021). A vaccination program against COVID-19 could substantially alleviate the problems related to the spread of the virus. A report from The ASEAN Post (2021), the Philippine administration is keen to implement its national COVID-19 vaccination program. The government is now securing procurement of COVID-19 vaccines from several manufacturers ensuring a sufficient dose of vaccine for synchronize and wellrounded vaccination for all Filipinos. On the other hand, various Local Government Units (LGUs) have secured vaccines from vaccine developers for their respective constituents following a tripartite agreement between the national government, vaccine manufacturers and themselves. The challenge for the government will be to encourage people to receive the vaccine (Fadda \& Albanese, 2020).

Vaccine hesitancy, the hesitation of patients to receive vaccines despite availability of vaccine services, has been identified by the World Health Organization as one of the top ten threats to global health (World Health Organization, 2019) making it a risk in the delay in acceptance of the immunization. Thus, instead of aiming to lower the cases this could result high-risk of infection.

Several factors affect an individual on responding the vaccination program such as the community he/she lives in, socio-economic background, their gender or profession, among others. Social media plays an important role in disseminating information about the development of COVID-19 vaccines. Spreading disinformation and misinformation from different social medias may lead to an individual enquiring the credibility of the vaccines. Vaccine hesitancy is rampant, fueled and abetted by social media, such resulting false claims for what should be a highly anticipated and avidly sought COVID-19 vaccine (Greech, Bonnici \& Zammit, 2020).

This survey will assess the willingness to VSU constituents to be vaccinated against COVID-19. This study will therefore provide a general picture on how faculty, staff and students of VSU will respond in the perceived risk and the intent to get vaccinated by commercialized COVID-19 vaccines. Results of the study will provide summary as to the confidence or doubts of the VSU constituents towards COVID-19 vaccines. Results of the study will provide input decision makers, health works or administrators that can facilitate the conduct of successful vaccination program.

\section{Objectives of the Study}

This study aims to assess willingness of VSU constituents to be vaccinated against COVID-19. Specifically, we aim to:

1. describe the socio-demographic characteristics and conditions confronting the VSU faculty, staff and students during this period of the COVID-19 pandemic;

2. identify the gender differences in the willingness or hesitancy to get vaccinated against COVID-19;

3. determine factors affecting the vaccine hesitancy of VSU constituents;

\section{METHODOLOGY}

\section{Data Collection}

Data was collected online via Google forms because of mobility and social restrictions during the COVID-19 pandemic. The online form was pre-tested to 10 respondents to determine if there was a need to change complicated and/or omit unnecessary questions. Comments and suggestions by the pre-tested respondents were taken into account. After pre-testing, the online form was revised prior to the final data collection. The online form was open for one (1) week from February 10-16, 2021.

The google form was e-mailed to all faculty and staff of Visayas State University (VSU). This includes teaching faculty, faculty-researchers, administrative staff and research and extension personnel. VSU Students are also asked to answer the online form in cooperation with the University Supreme Student Council. The online form was also posted to the official Facebook page of the Visayas Socio-Economic Research and Data Analytics Center(ViSERDAC).

With difficulty in the selection of a random sample, a convenience sampling, a non-probabilistic technique, was administered for the selection of respondents. It is noted that participation to the survey is voluntary and no respondent was forced to participate. 


\section{Data Analysis}

Data cleaning was done prior to the data analysis. Recoding of string variables and omitting of invalid responses were also done. Descriptive statistics was undertaken in a genuine licensed software of IBM SPSS Statistics version 26 and Microsoft Excel.

\section{Ethical Clearance}

The study sought approval by the university through its Visayas Socio-Economic Research and Data Analytics Center (ViSERDAC-001) in January 2021.

\section{RESULTS AND DISCUSSION}

\section{Profiling of Respondents}

A total of 401 respondents answered the survey. More than half of the respondents are female constituting $62.1 \%$ of the sample, whereas males constitute $37.9 \%$ (Table 1). These respondents are mostly faculty $(39.4 \%)$, students encompassing undergraduate and graduate students (36.4\%), and staff comprising administrative and research personnel $(24.2 \%)$ of the Visayas State University (Table 2$)$.

The average age of the respondents is 37 years old (Table 3). Female resulted to be much older with an average age of 40 years than males at 32 years old. Majority of both sexes are single (63.1\%) followed by those who are married (32.7\%). In addition, both groups have mostly attained Bachelor's degree (39.8\%), followed by Master's degree $(21.3 \%)$ and secondary $(18.6 \%)$. With this level of education, it is expected that most of them are earning less than or equal to 20,000 pesos with $54.2 \%$ of females and $42.8 \%$ of males, or earning 20,001-40,000 pesos per month (i.e., $29.3 \%$ of females and $33.6 \%$ of males).

The respondents have an average household size of 5 members in the family, with one (1) Senior Citizen aged 60 years old and above and one (1) minor aged 17 years old and below. Majority are located in a rural area for both sexes (76.8) and only a quarter are living in an urban area.

Table 1: Frequency of Male and Female Respondents

\begin{tabular}{|l|c|c|}
\hline Sex & $\mathbf{n}$ & $\mathbf{\%}$ \\
\hline Female & 249 & 62.1 \\
\hline Male & 152 & 37.9 \\
\hline Total & 401 & 100.0 \\
\hline
\end{tabular}

Table 2: Type of Respondent Disaggregated by Sex

\begin{tabular}{|l|c|c|c|c|c|c|}
\hline \multirow{2}{*}{$\begin{array}{l}\text { Type of } \\
\text { Respondent }\end{array}$} & \multicolumn{2}{|c|}{ Female } & \multicolumn{2}{c|}{ Mal } & \multicolumn{2}{c|}{ Total } \\
\cline { 2 - 7 } & Count & $\begin{array}{c}\text { Column } \\
\mathrm{N} \%\end{array}$ & Count & $\begin{array}{c}\text { Column } \\
\mathrm{N} \%\end{array}$ & Count & $\begin{array}{c}\text { Column } \\
\mathrm{N} \%\end{array}$ \\
\hline Faculty & 87 & 34.9 & 71 & 46.7 & 158 & 39.4 \\
\hline Staff & 73 & 29.3 & 24 & 15.8 & 97 & 24.2 \\
\hline Student & 89 & 35.7 & 57 & 37.5 & 146 & 36.4 \\
\hline Total & 249 & 100 & 152 & 100 & 401 & 100 \\
\hline
\end{tabular}

Table 3: Socio-Demographic Characteristics Disaggregated by Sex

\begin{tabular}{|c|c|c|c|c|c|c|c|c|c|c|}
\hline \multirow{2}{*}{\multicolumn{2}{|c|}{ Socio-demographic Characteristics }} & \multicolumn{3}{|c|}{ Female } & \multicolumn{3}{|c|}{ Male } & \multicolumn{3}{|c|}{ Total } \\
\hline & & \multirow{2}{*}{$\begin{array}{c}\text { Mean } \\
40\end{array}$} & \multirow[t]{2}{*}{$\mathrm{n}$} & \multirow[t]{2}{*}{$\%$} & \multirow{2}{*}{$\frac{\text { Mean }}{32}$} & \multirow[t]{2}{*}{$\mathrm{n}$} & \multirow[t]{2}{*}{$\%$} & \multirow{2}{*}{$\begin{array}{c}\text { Mean } \\
37\end{array}$} & \multirow[t]{2}{*}{$\mathrm{n}$} & \multirow[t]{2}{*}{$\%$} \\
\hline $\begin{array}{l}\text { Age } \\
\text { (in years) }\end{array}$ & & & & & & & & & & \\
\hline \multirow{6}{*}{ Marital Status } & $\begin{array}{l}\text { Common-law } \\
\text { husband/wife }\end{array}$ & & 3 & 1.2 & & & & & 3 & 0.7 \\
\hline & Married & & 81 & 32.5 & & 50 & 32.9 & & 131 & 32.7 \\
\hline & Separated & & 6 & 2.4 & & 3 & 2.0 & & 9 & 2.2 \\
\hline & Single & & 155 & 62.2 & & 98 & 64.5 & & 253 & 63.1 \\
\hline & Widowed & & 4 & 1.6 & & 1 & 0.7 & & 5 & 1.2 \\
\hline & Total & & 249 & 100.0 & & 152 & 100.0 & & 401 & 100.0 \\
\hline \multirow{7}{*}{ Monthly income } & $\begin{array}{l}\text { less than and equal to } \\
20,000\end{array}$ & & 135 & 54.2 & & 65 & 42.8 & & 200 & 49.9 \\
\hline & $20,001-40,000$ & & 73 & 29.3 & & 51 & 33.6 & & 124 & 30.9 \\
\hline & $40,001-60,000$ & & 12 & 4.8 & & 11 & 7.2 & & 23 & 5.7 \\
\hline & $60,001-80,000$ & & 11 & 4.4 & & 6 & 3.9 & & 17 & 4.2 \\
\hline & $80,001-100,000$ & & 6 & 2.4 & & 5 & 3.3 & & 11 & 2.7 \\
\hline & Above 100,000 & & 12 & 4.8 & & 14 & 9.2 & & 26 & 6.5 \\
\hline & Total & & 249 & 100.0 & & 152 & 100.0 & & 401 & 100.0 \\
\hline
\end{tabular}




\begin{tabular}{|c|c|c|c|c|c|c|c|c|c|c|}
\hline \multirow{11}{*}{$\begin{array}{l}\text { Highest } \\
\text { Educational } \\
\text { Attainment }\end{array}$} & Secondary & & 46 & 18.6 & & 26 & 17.1 & & 72 & 18.0 \\
\hline & SHS & & 1 & 0.4 & & 0 & 0.0 & & 1 & 0.3 \\
\hline & Vocational & & 4 & 1.6 & & 6 & 3.9 & & 10 & 2.5 \\
\hline & College Level & & 7 & 2.8 & & 3 & 2.0 & & 10 & 2.5 \\
\hline & Bachelor's Degree & & 106 & 42.9 & & 53 & 34.9 & & 159 & 39.8 \\
\hline & Master's & & 48 & 19.4 & & 37 & 24.3 & & 85 & 21.3 \\
\hline & Lawyer & & 0 & 0.0 & & 1 & 0.7 & & 1 & 0.3 \\
\hline & Medicine & & 1 & 0.4 & & 0 & 0.0 & & 1 & 0.3 \\
\hline & Doctoral & & 33 & 13.4 & & 24 & 15.8 & & 57 & 14.3 \\
\hline & Post-Doctoral & & 1 & 0.4 & & 2 & 1.3 & & 3 & 0.8 \\
\hline & Total & & 247 & 100.0 & & 152 & 100.0 & & 399 & 100.0 \\
\hline \multicolumn{2}{|c|}{ Household Size } & 5 & & & 5 & & & 5 & & \\
\hline \multicolumn{2}{|c|}{$\begin{array}{l}\text { Number of Senior Citizens in the } \\
\text { household ( } 65 \text { years old and above) }\end{array}$} & 1 & & & 1 & & & 1 & & \\
\hline \multicolumn{2}{|c|}{$\begin{array}{l}\text { Number of Minors in the household } \\
\text { (17 years old and below) }\end{array}$} & 1 & & & 1 & & & 1 & & \\
\hline \multirow{3}{*}{ Location } & Rural & & 194 & 77.9 & & 114 & 75.0 & & 308 & 76.8 \\
\hline & Urban & & 55 & 22.1 & & 38 & 25.0 & & 93 & 23.2 \\
\hline & Total & & 249 & 100.0 & & 152 & 100.0 & & 401 & 100.0 \\
\hline
\end{tabular}

\section{Perceived Health Status of Respondents}

Respondents are also asked regarding their current health status and if they have been infected with the virus. Three-quarters of both sexes $(75 \%)$ have not tested positive with COVID-19 (Table 4). Almost a quarter $(24 \%)$ of the respondents indicated that they cannot tell or are not sure because they have not undergone any related tests to COVID-19. More females have known someone who have been tested positive for COVID-19 (50.6\%) than males. More males, on the other hand, have not known anyone who are COVID-19 positive (56.6\%). Nonetheless, majority of both sexes rated their over-all health as good (44.4\%) and very good (37\%) Mukattash et al., (2020).

Table 4: Perceived Health Status of Respondents Disaggregated by Gender

\begin{tabular}{|c|c|c|c|c|c|c|c|}
\hline & & \multicolumn{2}{|c|}{ Female } & \multicolumn{2}{|c|}{ Male } & \multicolumn{2}{|c|}{ Total } \\
\hline & & $\mathrm{n}$ & $\%$ & $\mathrm{n}$ & $\%$ & $n$ & $\%$ \\
\hline \multirow[t]{4}{*}{$\begin{array}{l}\text { Have you ever tested } \\
\text { positive for COVID-19 }\end{array}$} & $\begin{array}{l}\text { Can't tell, I did not have } \\
\text { any COVID }-19 \text { related } \\
\text { tests }\end{array}$ & 60 & 24.1 & 37 & 24.3 & 97 & 24.2 \\
\hline & No & 187 & 75.1 & 115 & 75.7 & 302 & 75.3 \\
\hline & Yes & 2 & .8 & 0 & 0.0 & 2 & 0.5 \\
\hline & Total & 249 & 100.0 & 152 & 100.0 & 401 & 100.0 \\
\hline \multirow{3}{*}{$\begin{array}{l}\text { Have known someone } \\
\text { who have tested positive } \\
\text { for COVID-19 }\end{array}$} & No & 123 & 49.4 & 86 & 56.6 & 209 & 52.1 \\
\hline & Yes & 126 & 50.6 & 66 & 43.4 & 192 & 47.9 \\
\hline & Total & 249 & 100.0 & 152 & 100.0 & 401 & 100.0 \\
\hline \multirow{5}{*}{$\begin{array}{l}\text { Rating of over-all } \\
\text { PHYSICAL health }\end{array}$} & Poor & 3 & 1.2 & 4 & 2.6 & 7 & 1.7 \\
\hline & Neutral & 40 & 16.1 & 29 & 19.1 & 69 & 17.2 \\
\hline & Good & 115 & 46.2 & 63 & 41.4 & 178 & 44.4 \\
\hline & Very Good & 91 & 36.5 & 56 & 36.8 & 147 & 36.7 \\
\hline & Total & 249 & 100.0 & 152 & 100.0 & 401 & 100.0 \\
\hline
\end{tabular}

\section{Worry on the Effectiveness of COVID-19 Vaccines}

Tables 5 and 6 presents the respondents' perception and attitude towards COVID-19 vaccines and vaccination, respectively. Results have shown that more females have agreed (49.4\%) and strongly agreed $(29.3 \%)$ that they are worried of the effectiveness of the
COVID-19 vaccines than males (Table 5). Similarly, majority of males $(40.1 \%)$ have indicated to be worried of its effectiveness, however, in terms of proportion of respondents, there are relatively more males who are not worried (15.8\%) or are neutral (23.7\%) of the COVID19 vaccines' effectiveness than females. 
Table 5 : Perception on The Effectiveness of COVID-19 Vaccines

\begin{tabular}{|c|c|c|c|c|c|c|c|}
\hline \multirow{2}{*}{\multicolumn{2}{|c|}{ Perception about COVID-19 Vaccines }} & \multicolumn{2}{|c|}{ Female } & \multicolumn{2}{|c|}{ Male } & \multicolumn{2}{|c|}{ Total } \\
\hline & & $\mathrm{n}$ & $\%$ & $\mathrm{n}$ & $\%$ & $\mathrm{n}$ & $\%$ \\
\hline \multirow{6}{*}{$\begin{array}{l}\text { I worry about the } \\
\text { effectiveness of the } \\
\text { COVID-19 } \\
\text { vaccine. }\end{array}$} & 1 - Strongly disagree & 5 & 2.0 & 5 & 3.3 & 10 & 2.5 \\
\hline & 2 - Disagree & 14 & 5.6 & 24 & 15.8 & 38 & 9.5 \\
\hline & 3 - Unsure & 34 & 13.7 & 36 & 23.7 & 70 & 17.5 \\
\hline & 4 - Agree & 123 & 49.4 & 61 & 40.1 & 184 & 45.9 \\
\hline & 5 - Strongly Agree & 73 & 29.3 & 26 & 17.1 & 99 & 24.7 \\
\hline & Total & 249 & 100.0 & 152 & 100.0 & 401 & 100.0 \\
\hline
\end{tabular}

In terms of their attitude towards COVID-19 vaccination, both sexes are unsure (i.e. $26.1 \%$ of females and $26.3 \%$ of males) if they will receive the vaccine after many people receive and get vaccinated (Table 6). However, a higher proportion of females have agreed $(37.8 \%)$ that they will only get vaccinated after many other people receive the vaccine than males $(26.3 \%)$. Relatively more males have disagreed with this statement than females. This result implies that males are less worried about the COVID-19 vaccines and will not wait for other people to get vaccinated before they receive the vaccine as expressions of care (Acob, 2018) towards family members. Meanwhile, females are the opposite. They are more worried of its effectiveness and their decision of getting vaccinated may depend on the number of people receiving the vaccine.

Table 6: Attitude Towards COVID-19 Vaccination

\begin{tabular}{|c|c|c|c|c|c|c|c|}
\hline \multirow{2}{*}{\multicolumn{2}{|c|}{ Attitude towards COVID-19 Vaccination }} & \multicolumn{2}{|c|}{ Female } & \multicolumn{2}{|c|}{ Male } & \multicolumn{2}{|c|}{ Total } \\
\hline & & $\mathrm{n}$ & $\%$ & $\mathrm{n}$ & $\%$ & $\mathrm{n}$ & $\%$ \\
\hline \multirow{6}{*}{$\begin{array}{l}\text { I will only receive } \\
\text { the COVID }-19 \\
\text { vaccine after many } \\
\text { other people receive } \\
\text { the vaccine. }\end{array}$} & 1 - Strongly disagree & 12 & 4.8 & 17 & 11.2 & 29 & 7.2 \\
\hline & 2 - Disagree & 33 & 13.3 & 37 & 24.3 & 70 & 17.5 \\
\hline & 3 - Unsure & 65 & 26.1 & 40 & 26.3 & 105 & 26.2 \\
\hline & 4 - Agree & 94 & 37.8 & 40 & 26.3 & 134 & 33.4 \\
\hline & 5 - Strongly Agree & 45 & 18.1 & 18 & 11.8 & 63 & 15.7 \\
\hline & Total & 249 & 100.0 & 152 & 100.0 & 401 & 100.0 \\
\hline
\end{tabular}

\section{Knowledge on the COVID-19 Vaccines}

Before asking the willingness of respondents of getting vaccinated from COVID-19, they are first to assess their level of knowledge on the COVID-vaccines. Table 7 shows that majority of the respondents have indicated to have substantial knowledge on the COVID19 vaccines $(58.4 \%)$. However, it is interesting to note that more males $(64.5 \%)$ of the respondents have substantial knowledge on the vaccines than females $(54.6 \%)$. While more females $(44.6 \%)$ indicated to have little knowledge on this aspect than males (34.6\%). Moreover, both sexes have obtained this information mostly from television news $(92.8 \%)$, social media platforms like Facebook, Instagram, Twitter, etc. (82\%), internet search (57.8) and family and friends.

Table 7: Knowledge on COVID-19 Vaccines

\begin{tabular}{|c|c|c|c|c|c|c|c|}
\hline & \multicolumn{2}{|c|}{ Female } & \multicolumn{2}{|c|}{ Male } & \multicolumn{2}{|c|}{ Total } \\
\hline & & $\mathrm{n}$ & $\%$ & $\mathrm{n}$ & $\%$ & $\mathrm{n}$ & $\%$ \\
\hline \multirow{4}{*}{$\begin{array}{l}\text { Knowledge on } \\
\text { COVID-19 Vaccines }\end{array}$} & None & 2 & .8 & 2 & 1.3 & 4 & 1.0 \\
\hline & A little & 111 & 44.6 & 52 & 34.2 & 163 & 40.6 \\
\hline & Substantial & 136 & 54.6 & 98 & 64.5 & 234 & 58.4 \\
\hline & Total & 249 & 100.0 & 152 & 100.0 & 401 & 100.0 \\
\hline \multirow{10}{*}{$\begin{array}{l}\text { Source of } \\
\text { information on the } \\
\text { COVID-19 } \\
\text { Vaccines* }\end{array}$} & Academic Journals & & & 1 & 0.7 & 1 & 0.3 \\
\hline & Family/Friends & 139 & 56.0 & 74 & 48.7 & 213 & 53.3 \\
\hline & Internet Search & 139 & 56.0 & 92 & 60.5 & 231 & 57.8 \\
\hline & Radio & 76 & 30.6 & 51 & 33.6 & 127 & 31.8 \\
\hline & School & 1 & 0.4 & & & 1 & 0.3 \\
\hline & Seminars & 1 & 0.4 & & & 1 & 0.3 \\
\hline & signages & 1 & 0.4 & & & 1 & 0.3 \\
\hline & Social Media (FB, IG, etc) & 198 & 79.8 & 130 & 85.5 & 328 & 82.0 \\
\hline & Subjects handled & 1 & 0.4 & & & 1 & 0.3 \\
\hline & TV news & 229 & 92.3 & 142 & 93.4 & 371 & 92.8 \\
\hline
\end{tabular}

*Multiple response

60| VOL. 13 (2) October 2021 | THE MALAYSIAN JOURNAL OF NURSING 


\section{Willingness of Respondents to Get Vaccinated}

More than half of the respondents are willing to get vaccinated against COVID-19 (54.6\%) and have no preference for a specific type of COVID-19 vaccine $(54.9 \%)$ (Table 8 ). Around $30.4 \%$ are still unsure if they should get vaccinated or not and $15 \%$ have indicated negatively. Comparing both sexes, a larger frequency of males are willing to get vaccinated constituting $69.1 \%$ than females $(45.8 \%)$. Consequently, more females $(38.6 \%)$ are quite unsure of their decision than males
(17.1\%). They have also no preference for a specific type of vaccine $(58.6 \%)$ than males $(48.7 \%)$. This could be because more females have indicated to have a little knowledge on the COVID-19 vaccines and more males indicated to have substantial knowledge on these area as described in Table 7. This result implies that males tend to be more willing to get vaccinated because they tend to be more knowledgeable about the COVID-19 as vaccination program and strategy being part of the positive effects (Acob, 2020) of this global health crisis.

Table 8: Knowledge On COVID-19 Vaccines

\begin{tabular}{|c|c|c|c|c|c|c|c|}
\hline & \multicolumn{2}{|c|}{ Female } & \multicolumn{2}{|c|}{ Male } & \multicolumn{2}{|c|}{ Total } \\
\hline & & $\mathrm{n}$ & $\%$ & $\mathrm{n}$ & $\%$ & $\mathrm{n}$ & $\%$ \\
\hline \multirow{4}{*}{$\begin{array}{l}\text { Willingness to get } \\
\text { vaccinated }\end{array}$} & No & 39 & 15.7 & 21 & 13.8 & 60 & 15.0 \\
\hline & Unsure & 96 & 38.6 & 26 & 17.1 & 122 & 30.4 \\
\hline & Yes & 114 & 45.8 & 105 & 69.1 & 219 & 54.6 \\
\hline & Total & 249 & 100.0 & 152 & 100.0 & 401 & 100.0 \\
\hline \multirow{3}{*}{$\begin{array}{l}\text { Having preference on } \\
\text { a specific COVID - } 19 \\
\text { vaccine }\end{array}$} & No preference & 146 & 58.6 & 74 & 48.7 & 220 & 54.9 \\
\hline & Yes & 103 & 41.4 & 78 & 51.3 & 181 & 45.1 \\
\hline & Total & 249 & 100.0 & 152 & 100.0 & 401 & 100.0 \\
\hline
\end{tabular}

When asked to rank the COVID-19 vaccines, majority of both sexes (56.4\%) ranked Pfizer-BioNTech as their first choice (Table 9). This is followed by $19.1 \%$ of the respondents choosing AstraZeneca and $10.1 \%$ on Moderna. Few (6.3\%) have selected Sinovac (6.3\%), ranking fourth, and Johnson \& Johnson (3.3\%) ranking fifth.

Table 9: Ranking of the COVID-19 Vaccines

\begin{tabular}{|l|c|c|c|c|c|c|}
\hline \multirow{2}{*}{ COVID-19 Vaccines } & \multicolumn{2}{|c|}{ Female } & \multicolumn{2}{c|}{ Male } & \multicolumn{2}{c|}{ Total } \\
\cline { 2 - 7 } & $\mathrm{n}$ & $\%$ & $\mathrm{n}$ & $\%$ & $\mathrm{n}$ & \multicolumn{2}{c|}{$\%$} \\
\hline Pfizer-BioNTech & 115 & 58.4 & 74 & 53.6 & 189 & 56.4 \\
\hline AstraZeneca & 43 & 21.8 & 21 & 15.2 & 19.1 \\
\hline Moderna & 20 & 10.2 & 14 & 10.1 & 34 & 10.1 \\
\hline Sinovac & 9 & 4.6 & 12 & 8.7 & 21 & 6.3 \\
\hline Johnson \& Johnson & 3 & 1.5 & 8 & 5.8 & 11 & 3.3 \\
\hline Sputnik V & 4 & 2.0 & 6 & 4.3 & 10 & 3.0 \\
\hline Novavax & 3 & 1.5 & 3 & 2.2 & 6 & 1.8 \\
\hline Total & 197 & 100.0 & 138 & 100.0 & 335 & 100.0 \\
\hline
\end{tabular}

\section{Willingness to Pay}

Table 10 shows the willingness of respondents to pay for a single dose of COVID-19 vaccine. Interestingly, results show that most of the respondents constituting $36.5 \%$ of the sample are not willing to pay. They reasoned that it should be made free by the government. Comparing the two groups, most males (36.9\%) are willing to pay Php 501 to 2000 pesos while majority of females are not willing to pay. This result suggest that males are more willing to spend higher than females. Only very few $(7.1 \%)$ are willing to pay Php 2001 and above.

Table 10: Willingness to Pay for A Single Dose of COVID-19 Vaccine

\begin{tabular}{|l|c|c|c|c|c|c|}
\hline \multirow{2}{*}{} & \multicolumn{2}{|c|}{ Female } & \multicolumn{2}{c|}{ Male } & \multicolumn{2}{c|}{ Total } \\
\cline { 2 - 7 } & $\mathrm{n}$ & $\%$ & $\mathrm{n}$ & $\%$ & $\mathrm{n}$ & \multicolumn{2}{c|}{14} \\
\hline 0, not willing to pay & 95 & 38.80 & 49 & 32.90 & 36.50 \\
\hline $1-500$ & 73 & 29.80 & 30 & 20.10 & 103 & 26.10 \\
\hline $501-2000$ & 64 & 26.10 & 55 & 36.90 & 119 & 30.20 \\
\hline 2001 and above & 13 & 5.30 & 15 & 10.10 & 28 & 7.10 \\
\hline Total & 245 & 100.00 & 149 & 100.00 & 394 & 100.00 \\
\hline
\end{tabular}




\section{CONCLUSION}

With the on-going global mass vaccination program to attain herd immunity, education and continuous campaign are at par to succeed in combating the health crisis. Generally, males are more willing to receive the inoculation, regardless of the type and brand of vaccines for COVID-19. Moreover, gender issues should not be the bases of whether or not vaccination proceeds understandably because health and safety are the major considerations these trying times. Males in general are agreeing for inoculation operates on the patriarchal premise that a man by all means maintains his paternal obligation of raising his family. Reflective of findings that women's willingness to be vaccinated indicates her maternal instincts to secure her children's welfare tops her priorities over one's desire. It is therefore recommended that vaccination both as a program and intervention must be based on gender and individual preferences to accommodate individual desires and respect for culture.

\section{Conflict of Interest}

The authors declare that they have no conflict of interest.

\section{ACKNOWLEDGMENT}

The entire research team expressed their gratitude to the Visayas State University, its administrators, faculty and staff for participating in the survey.

\section{REFERENCES}

Acob, J. R. U. (2018). Caring as Unending Expression of Nursing (CUEN): A theory of nursing. The Malaysian Journal of Nursing (MJN), 10(2), 52-57.

Acob, J. R. U. (2020). Appreciating positivity of COVID-19. Belitung Nursing Journal, 6(6), 226-228.

Fadda, M., Albanese, E., \& Suggs, L. S. (2020). When a COVID-19 vaccine is ready, will we all be ready for it? International Journal of Public Health, 65(6), 711-712.

Grech, V., Bonnici, J., \& Zammit, D. (2020). Vaccine hesitancy in Maltese family physicians and their trainees vis-a-vis influenza and novel COVID-19 vaccination. Early Human Development.

Mukattash, T. L., Jarab, A. S., Abu-Farha, R. K., Nusair, M., Mukattash, I. L., Obaidat, R. M., Khdour, M., Basheti, I., (2020). Willingness and readiness to test for COVID-19; A qualitative exploration of community pharmacists. International Journal of Clinical Practice, 74(12), e13620.

Mundra, A., \& Garg, B. S. (2020). Prospects of Vaccine against COVID-19. Indian Journal of Community Medicine: Official Publication of Indian Association of Preventive \& Social Medicine, 45(4), 391.

The ASEAN. (2021). Covid-19 Vaccines for All. Double Issue August-September 2021. https://asean.org/wpcontent/uploads/2021/10/The-ASEAN-Vaccines-For-All-August-Sept-2021.pdf

World Health Organization (2019). Ten Threats to Global Health in 2019. https://www.who.int/newsroom/spotlight/ten-threats-to-global-health-in-2019. 